\title{
How Vasily Shukshin Celebrated the Fiftieth Anniversary of the October Revolution
}

\author{
Vladimir K.Sigov* \\ Moscow State Pedagogical University \\ 1/1 M. Pirogovskaya Str., Moscow, 119991, Russia
}

Received 19.01.2017, received in revised form 02.03.2018, accepted 15.03.2018

The article analyzes the 1966-1968 cycle of V.M. Shukshin's stories which were his direct response to the approaching fiftieth anniversary of the Great October Socialist Revolution. The stories "Mil' pardon, madam!" ("Mille Rardons, Madam!"), "Zarevoi dozhd"” ("The Rain at the Dawn"), "Kapronovaia elochka" ("Kapron Christmas Tree"), "Nechaiannyi vystrel" ("Accidental Shot"), "Okhota zhit"” ("Hunting to Live"), "Operatsiia Efima P'ianykh" ("Efim P'ianykh's Operation") are characterized by a common manner of narration and form the writer's cycle of works about the folk's national character and its evolution under the influence of the events in the first half of the 20th century. The article mainly focuses on the fairy-tale novel "Tochka Zreniia" ("Point of View") which arouses interest as it clearly reveals the writer's artistic tools that are more naturally applied in the anniversary prose cycle.

Keywords: "a man with a gun", intertextuality, national character, the theme of collectivization, cyclization of short stories, subtext / underlying theme / implication, poetics.

DOI: 10.17516/1997-1370-0240.

Research area: philology.

\section{Introduction}

The literary criticism still does not provide with the unanimous understanding of which spiritual, ideological, political, and esthetic criteria were constitutive for V.M. Shukshin. During his life and in the first decade after his death he was predominantly characterized as a fairly consistent socialist realist. Only the characteristics of being "socialist" was shaded down and mentioned as standard and taken for granted (Apukhtina, 1986; Emelianov, 1983; Karpova, 1986; Tolchenova, 1982). The writer himself complained about the insufficiency of this approach, which, in his opinion, makes creativity rough and stupid: "They, the devils, don't want to think it through. Or can't. Both, probably" (Shukshin, 1998, Vol. 6: 411). It should be noted, however, that, compared to artistic creation, criticism is always less free from the ideology dominating in society and more unambiguously aimed at achieving specific socio-political goals which serve a particular ideological and philosophical doctrine. A slightly different point of view was most consistently supported by L. Anninskii in the Soviet period of the literary reflection of the writer's heritage. In a veiled

(C) Siberian Federal University. All rights reserved

* Corresponding author E-mail address: vladimirsigov@mail.ru 
form, he pointed out to a sense of confrontation between his heroes and the writer himself with the civilization and culture, the peasant with the city as Shukshin's key creative intention. With a shank in a boot-top they hide in dark alleys for poor intelligent "citizens": "Maliciously and acutely the emotion flashes in the stories, turns into a joke, fable, grin at the right moment, and then suddenly stabs, doing it unexpectedly and with lightning speed" (O Shukshine, 1986: 124).

In the 90 s they prove the conception of Shukshin being an antitheist who focuses on national pre-Christian spirituality (Chernosvitov, 1989), a fighter with the system of the dissident doctrine (Vertlib, 1990). At that time, a tendency of ideology-free semiotically profound linguistic analysis of Shukshin's prose was formed (Kozlova, 1992), a peculiar result of this phase being "Shukshinskaia entsiklopediia" ("Shukshin Encyclopedia") (Shukshinskaia entsiklopediia, 2011). We mention talented and bright works that have outlined the trends typical for many researchers.

In our opinion, there is a corpus of Shukshin's works, the analysis of which makes it possible to define the interaction of the ideological and the formal in his creative work with greater evidence and to update the most important ideas about the nature of his artistic methodology, conception of modern national history.

\section{Problem Statement}

In $1966-1968$ in connection with the $50^{\text {th }}$ anniversary of the revolution the society's interest in historical and revolutionary problems got increased. Shukshin did not seek, of course, for formal response to the calls to reflect historical and revolutionary themes in his works. His interest in the problem was consistent, profound and serious. At that time he creates a cycle of works in which folk characters are considered as determined by national destiny and influence on it. This theme was also developed by the writer in the future. These are textbook images and motifs, that became indispensable attributes of any conversation about the "issue of the Great October Revolution in the Soviet literature" by the mid 1960s, that often mark the main subject of the writer's interest. It is, for example, a "mangy dog" from Dvennadtsat' (The Twelve) symbolizing "the old world". This image, as well as the image of the twelve "apostles" of the new world, is quite consistently used in Shukshin's prose in the same function but with slightly changed accents. It was Lelia Selezneva who already described the exact way "the twelve people worked without a moment's rest" (the short story Lelia Selezneva s Fakul'teta Zhurnalistiki (Lelia Selezneva from the Journalism Department (1962)). Religiousand-philosophical and revolutionary-andromantic symbols are consistently used in the works of 1966-1967 and later.

In the story Nachal'nik (The Boss) it is not only number 12 , the number being that of the wood-cutters who were trapped by the storm in a forest hut, that makes one remember the picture by Blok, but also the landscape: "S gor sorvalsia uprugii, zloi veter, dolina zagudela. Lezhalyi sneg podnialsia $\mathrm{v}$ vozdukh, sdelalos' temno. Dvoe sutok na zemle i na nebe revelo i vylo" ("A springy, evil wind broke from the mountains, the valley started buzzing. The stale snow rose into the air, and it got dark. For two days it had been roaring, howling on earth and in the sky"). "Veter, veter - / na vsem bozh'em svete..." (The wind, the wind! / Blowing across God's world!"). The collective portrait of Shukshin's twelve wood-cutters display the features that are similar to those of Blok's twelve (for example, the staging camp past of some of them - "na spinu b nado bubnovy tuz" ("All that's missing is prison stripes!")).

During this period the writer acquires creative maturity, develops the principles of 
aesthetic expression which are the most natural for him and enable to express the main things in the conditions of censored creativity. Such stories as Mil' Pardon, Madam! (Mille Rardons, Madam!), Zarevoi Dozhd' (The Rain at the Dawn), Chudik (Queer Devil), Daesh Serdtse! (Give the Heart), Bessovestnye (The Unscrupulous), Kapronovaia Elochka (Kapron Christmas Tree), Nechaiannyi Vystrel (Accidental Shot), Okhota Zhit' (Hunting to Live), V Profil' i Anfas (In Profile and FullFace), Raskas, Operatsiia Efima P'ianykh (Efim P'ianykh's Operation) are marked by a single manner of narrative and present the writer's cycle which is entirely aimed at identifying the ideas about the nature of the national character and its evolution under the influence of the events of the first half of the $20^{\text {th }}$ century. Serious iddues attract the writer's attention also in the future. Cherednichenko $i$ Tsirk (Cherednichenko and the Circus), Shtrikhi k Portretu (Strokes to the Portrait), Post Skriptum (Post Script), Krysha Nad Golovoi (The Roof over the Head) and a number of other works develop the observations over historical changes of the national character. With all this going on Shukshin still actively uses the manner of narrative peculiar for the Mil' Pardon, Madam! story.

\section{Chelovek s Ruzh'em (A Man with a Gun) as a Protagonist of the Post-Revolutionary Era}

The name of the character in the Mil' Pardon, Madam! story and the Rokovoi Vystrel film-novel is Bronislav Pupkov. He is literally the same age as the revolution is. The story was written in 1967 and first published in the November, a "redletter day" issue of the "Novy Mir" ("The New World") magazine in 1968. The character's age is over fifty. The words bronia ("armor") and slava ("glory"), constituting the root of the name, indicate the character's ancestral role and his task. He is often called Bron'ka.
Commenting on the perception of this story by the audience of the Rokovoi Vystrel filmnovel, Shukshin complained that "the audience could not take a run and failed to understand the hero; what they understood was the surface picture of the image which was the thing I do not value as a film director. Only a few of them guessed the character-parable" (Shukshin, 1998, Vol. 5: 533). It should be noted that the literary analysis of the story has long been built around the hero's moral-and-psychological characteristic features. This does not favour a proper evaluation of the idea of the writer, who counted on a much deeper reading. To understand this and other Shukshin's works it is important to take the emerging literary associations into account. E.F. Koniushenko noted that "the hero and the plot of the Mil' Pardon, Madam! story ... are focused on the Idiot novel or, more specifically, this novel's comic line represented by the images of Lebedev and primarily of those of the general Ivolgin" (Shukshin, 1997: 17). However, intertextual relations of the story are not limited to this direction. Their effect on the semantic field of the story is not autonomous. They interact with the semantic potentials of other artistic means in a very complex way.

Hunting trips put Bron'ka's path and goal, that were lost long ago, into semblance. In his youth, the index finger (a path) and the middle onefinger (a heart, middle) on his right hand were torn off. The true purpose and the core (support) were lost in the hero's life. He buried them himself - "do svetlogo utra" ("till the light morning"). At once, he tried to make the first action that distorted the meaning of the past rituals, the action of putting a cross over the fingers. The father did not let him do this, which was fully justified for Bron'ka. The cross marks the resting place of the body, awaiting its reunion with the spirit. This is the character's state. This is the reason of his soul thrashing about. 
Bron'ka makes the audience give their "chestnoe partiinoe slovo' ("party word of honour") about the non-disclosure. This further emphasizes the socio-political aspects of the subtext. He sort of wants to enlist the support of his colleagues from the group of adherents "born by the revolution".

The fact of the same date of Bron'ka's attempt and Shukshin's birthday (July 25, 1943) is supposedly a hint on a significant role of the writer's thoughts and ideas hidden beneath the surface of the narrative plot. Shuksin turned 14 then. His fortieth anniversary the writer "celebrated" in the story Moi Ziat' Ukral Mashinu Drov (My Son-in-Law Has Stolen a Truck of FuelWood). It is in the toilet where Venia Ziablitskii "locked" his mother-in-law who organized the first collective farm and later a small zone in her own house on July 25, 1969.

Continuing the line of direct and indirect historical, revolutionary, and autobiographical associations, he mentions the milestones which are most important not only in Bron'ka's life. They are also important for the historical path of his family generation, which is similar to the important events in Shukshin's family. Starting from the Cossacks who built a border fortress in Siberia under Peter the Great the line leads to the years of the "great change". In 1933, both the writer's father and the priest, who gave an unhappy name (bronia/armor and slava/glory) to a newborn child, were sent to GPU (the State Legal Directorate) apparently forever.

Stereotype views on the "cursed past" and the "bright future", which had been introduced to the mass consciousness, find their peculiar embodiment and evaluation in the story. Bron'ka bears a very close resemblance with the enemy, bourgeois bastard. In the process of preparation for an important historical achievement he reaches the consumer paradise (each according to his needs) which was associated with the communism idea in mass propaganda. The true "lofty" purpose to change and transform is veiled by Bron'ka as skillfully as it got encrypted in the philosophical terms and categories by the communist theory, the terms and categories being inaccessible to the mass consciousness. The task was the same to cover the empty "sacred place" with the concepts the masses could understand (food, drink, batmen-servants). Bron'ka's speech is full of propaganda clichés: predatel' (a traitor), vrag naroda (an enemy of the State). Similar to the programme party documents of the $60 \mathrm{~s}$, abundance of digital "specifics" in his reasoning is significant. These details contribute to clearer associations of Bron'ka's history with the history of socio-political and spiritual changes in the country. The speech of the general who blessed Bron'ka to a heroic action reflected even a certain eclecticism of spiritual cues that were allowed during the war when the concessions toward religion and the church were made in the name of salvation and victory: "S Bogom... Zhdem tebia ottuda Geroem Sovetskogo Soiuza" ("God bless you... Come back a Hero of the Soviet Union").

All this military and combat rhetoric, generally characteristic of the mass propaganda of the Soviet era, helps to recognize an allegorical image of the "new world" in Bron'ka's "distorted history". And he himself is to some extent a creator, this world's creator and its attribute to a much greater extent: he is obsessed with his "history" and has no power over himself.

Every detail turns out to be significant at the chosen manner of a secret dialogue with a "thinking and clever" one. Bron'ka lost his fingers while taking a shot in "zimnee vremia" ("winter time"). These words in the text of the story seem to be semantically redundant: indirect indications are enough to understand when it all took place. They stand out of a general course of the 
narrative both stylistically and even graphically: they are put in brackets. All this leads to thinking it over once again when the implication is already slightly open. Then it is quite logical to call to mind the Winter Palace, the storming of which began with a shot from "Aurora".

The symbols of the shot fingers may be associated with "their" meaning in the history of Old Belief. It is the sign of the cross with two fingers that was one of the religious rituals distinguishing the "old faith" from the "new one". Having lost his fingers as a result of a "fatal shot", the hero thus turned out to be symbolically separated from the "old faith" but cannot truly serve the "new" one.

The actor E. Lebedev recalled how sharply Shukshin reacted during the filming of the Rokovoi Vystrel movie when "off-camera there was a shot that was not in the scenario; involuntarily frightened, I yelled "e-e-e-e!.." and at that moment someone shouted "Stop!". But Shukshin started screaming: "Who has said "stop!"!? I would have played it! The shot would have gone into the film!" (Shukshin, 1998, Vol. 5: 435). The reaction was so harsh because the unexpected was also considered by the writer as a means to focus on the essential things.

Bron'ka Pupkov is not to be blamed for some sort of loss of his "path and goal", his destiny. In the idea of the plot of the Mille Rardons, Madam! movie Hitler was planned to be "like Gulliver among the Lilliputians, Gulliver being almighty and able to shoot with his fingers" (Shukshin, 1998, Vol. 5: 510). But Bron'ka's finger for shooting - the index one - was torn when Bron'ka was young, in the period of "great change". According to Shukshin, "twenty-five minutes" of Bron'ka's on-screen monologue "were enough to fit in the man's fate" (Shukshin, 1998, Vol. 5: 510).

The writer had a feeling that the film version of the story resulted in schematization of a set of images ("crutches" in Shukshin's words), so the Rokovoi Vystrel movie has the only detail of reference to historical-and-revolutionary problem, detail being the title of the movie. It is more specific than in a story that implies and requires slow reading. The "fatal shot" of "Aurora" marked the beginning of a "new era", the birth of the "new world" and a new, "crippled" man, preserving remarkable national strength but disoriented and shooting off the mark at the decisive moment.

"Bron'ka cries, holds the hand as if he was shooting" ("Bron'ka krichit, derzhit ruku, kak esli b on strelial") but he has nothing to "shoot" with. The attempt to "kill the bastard" failed: "Ia promakhnulsia..." ("I've shot off the mark..."). Bron'ka managed to distort his own history. But the soul, wounded "in the attack", incites him to the absurd, to replacement of life with imagination, which may require from the person not less emotion and fire than a worthy occupation. The denouement of the story once again emphasizes a crippled, awkward man's complexity, dramatic nature, which is as crippled and awkward as the western Polish name of Bronislaw that inoculated to the simple Russian surname of Pupkov. His conscience is still not "all lost"; and he himself is not sinless and is willing to increase the number of "crippled" souls: "Esli malost' izuvechu, proshu ne obizhat'sia" ("If I mutilate you a little, please, do not be offended").

Shukshin's hero is undoubtedly talented, solid, and purposeful: "Strelok on byl, Pravda, redkii" ("He was a truly rare shooter"). Even in a "distorted history" he managed to show a fascinating force and an enormous creative potential. However, his past and future paths are connected with the writer's disturbing thoughts about the unpredictability of a ready-to-goodand-evil and still "newborn" (the diminutive version of the word "navel") hero. 


\section{Foundation of the collected cycle of the stories Zarevoi Dozhd', “Operatsiia Efima P'ianykh", "Kukushkiny Slezy"}

Shukshin proceeded from a belief that it is impossible to "kill" the truth, but it is important not to hide it: "A sober and reasonable man is undoubtedly everywhere and always fully understands his time, knows the truth, and keeps it a secret if the circumstances are such that it is better to keep it a secret. A smart and talented man will definitely find a way to reveal the truth at least with a hint or a half-word. Otherwise, it will torture him and the life will be a waste of time, as it seems to him" (Shukshin, 1998, Vol. 3: 434). In the field of artistic form there gradually "emerges the writer's theory: "A shift of accents" when the main thing... is not to focus but show as abreast with the secondary ones. To imitate the naïve" (Shukshin, 1998, Vol. 6: 416).

Other components of the writer's theory are not mentioned, although he had been thinking of providing the details: "I will explain after I have got the understanding" (Shukshin, 1998, Vol. 6: 425). The analysis proves that it is the support on the textbook plot schemes and images that underlie "a hundred volumes... of party books" for mandatory reading that is one of the important and permanent ways to create a subtext in Shukshin's historical and philosophical cycle. The presence of such a foundation, "basis" is a characteristic feature of Shukshin's "50year" cycle as a whole. It is impossible to fully understand the writer's position in the stories printed in the same collection of stories (Zarevoi Dozhd', Operatsiia Efima P'ianykh, Kukushkiny Slezy) without taking into account this peculiar feature of their poetics. The writer thought of some interchanges that the readers were supposed to catch in the stories printed together.

The most important turn of the 50-year Soviet history is the period of collectivization, genuine social and economic revolution, which recognized the achievements of ideological and political and state ideological transformations in the life of the USSR. The theme of collectivization is one of the key ones in the cycle as well as in many other Shukshin's works. This is due to the extraordinary nature of this historic event. It significantly influenced the course of the national history in general and got reflected in the fate of many humans, including the writer himself and his family.

Shukshin managed to speak on acute issues of the national history "more freely" than it was possible in the censored literature of the 60s. It was because of his special manner of "hidden" dialogue with the readers. His stories are intertextually rich. Giving his interpretation of the classical "Soviet" subjects, such as Gorky's Pesnia o Sokole (Song of the Falcon), in the Zarevoi Dozhd' story, the writer artistically expresses the people's point of view on the most important national-and-historical turn in 19661967 already.

The period of radical breakdown of the existing way of life became the most important milestone in the fates of the story's main characters, Efim Bedarev and Kir'ka. They both can hardly be seen as passive victims of history. They had their active positions and fought with each other to the death. Their dispute continues till the last day of Efim's life. The writer's aim in the story is to some extent related to the evaluation of the historical past. The writer's position seems to be quite certain, if we proceed from the content of the story itself and especially if we take into consideration the ideas embodied throughout the cycle. Giving troubles to the people (which is the meaning of the surname of Bedarev), Efim dies hard and painfully, as Kir'ka predicted. It is not the enemy that got breathless with his blood ("Vraga prizhal by ia k grudi, i zakhlebnulsia b on krov'iu moei” / "I 
would press the enemy against the wounds in the chest for him to get breathless with my blood" "The Song of a Falcon") but he himself. At the last moment Efim agrees that not everything was done correctly: "Konechno, zhalko malost" ("Of course, I feel pity a bit"). However, the writer is mostly occupied not so much by the evaluation of the past, but by the analysis of a new state of the national life, which has developed on the basis of the conflicts going away. It is not a belated historical "revenge" of Kir'ka-kulak that is important for the writer, but an idea of the need and opportunity to overcome the most acute interpersonal clashes, social friction. The roots of the historical confrontation are evaluated differently, as compared to the official position. It is emphasized that the prospect of the national life is determined by overcoming it.

A figurative plot "scheme" of Gorky's romantic "Song..." is quite distinctly traced in the story. It is Kir'ka who has especially strong connections with earth. When he first appeared in the ward he "smelled soil and sheep", got onto the window sill and lay down. Efim, who did not still believe in his close death, greeted him with the words: "Ty dlia chego propolz siuda?" ("Why have you crawled in here?"). "Kir'ka spolz s podokonnika... snova leg na podokonnik" ("Kir'ka slipped from the window sill... lay on the window sill again"), forces this symbolism the narrator. Like the classic water snake, Kir'ka is clearly ready to outlive Bedarev-the Falcon and also wants to know the mystery of the dying man's struggle and faith. But it is not "a musty heat of marshy lowlands" that becomes the cause of Efim's death, but, as it has been already noted, his "internal disease", his own "blood".

Association with Gorky's another romantic work can be significant in the description of Efim's disease and death. Danko from the story Starukha Izergil' (The Old Woman Izergil') gave the people the fire of his hearts; whereas Efim's "fire" was not accepted and he burns from the heat from inside: “Bolezn'... zhgla gubitel'nym ognem: zharom dyshala $v$ litso, zharko, muchitel'no zharko bylo pod odeialom, $\mathrm{v}$ zharkom tumane kachalis' steny i potolok..." ("The disease... burned with the devastating fire: the heat breathed in the face, it was hot, painfully hot under the blanket, the walls and the ceiling swung in the hot fog..."). The content of the Zarevoi Dozhd' story, that is frankly polemically sharpened in relation to early Gorky's revolutionary and romantic ideas, pushes to such associations. The object of controversy is not so much Gorky but that meaning that was put to these ideas used in the propaganda in later time. Shukshin himself is more focused on ethical provisions formed on the basis of the people's common sense. In connection with the problem under consideration, they are most clearly expressed in Sholokhov's Podniataia Tselina (Virgin Soil Upturned). It is Sholokhov's national tradition that becomes the basis of a moral ideal, expressed by Shukshin in his Zarevoi Dozhd' story and in the Operatsiia Efima P'ianykh story published at the same time. The feelings of pathetics, uplift, and romantic elation are characteristic to the heroes, but they are hardly shown. They rarely appear on the surface, like a deep underlying thought of a man, who is indifferent in his understanding of all phenomena of existence. True drama and even tragedy do not exclude other feelings in people's life (these are, for example, humor and other feelings which the routine life is full of).

The author planned some common associations that the readers were supposed to catch in the stories published together. He even repeats the characters' names: these are Efim Bedarev and Efim P'ianykh, Bedarev's daughter's name and the name of the heroine of Kukushkiny Slezy (Cockoo's Tears) is the same, the name being Nina. They are of the same social position: Efim is the head of the "regional level", P'ianykh is the 
head of the collective farm. They both are in the same life situation. They are ill. But, compared to that of Bedarev, P'ianykh's disease is clearly of a low parody character. Parody associations can be traced with the Song of the Falcon (Efim calls his "enemy", a shell-splinter that remained in his body from the war, a "serpent") and Danko's Burning Heart legend. They help to evaluate the type of the hero depicted in the stories Zarevoi Dozhd' and Operatsiia Efima P'ianykh without taking into account a dramatic situation the hero was first involved in.

Efim performs a "bloody operation" on himself, trying to extract the splinter left by the war in his lower back, while "thinking about the people" in his subordination. His wishes them to follow him with faith but not with smiles. But the smile, according to the writer, is no barrier to life. Rich world view, organic combination of high and low, and ability to "embrace everything" are signs of a truly national attitude to life.

Kir'ka is not convinced by his former enemy's arguments, but, nevertheless, he is sincere with him. In the writer's evaluating system, "warm abundant rain" ("It is warm and damp") is a sign of reconciliation. It gives rise to hope for a revival and a rapid summer of life. The heroes' common national roots serve the basis for such conclusions. They got separated in their social life, but remained inextricably linked on an organic level. Many artistic details serve the evidences: Efim and Kir'ka are still very close to each other, they have common strokes of external behavior, preferences. Kir'ka "drew down with strong home-grown tobacco" ("zatianulsia treskuchim samosadom"); Efim also asks for a "couple of draws" ("paru raz kurnut") even at his last moment. In the end, a "flying" and a "crawling" men are on the same human level: in his neighbouring enemy's words Kir'ka has not "crawled", "lay down" but "came". The narrator's tone also changes: "Kir'ka... stoial u okna" ("Kirka... stood at the window"), whereas Efim has raged, "became heavy,... drooped" (“otiazhelel, ...obvis").

A detail uniting the heroes in perspective of their human persistence is particularly revealing. Kir'ka comes to his son-in-law; Efim has got only a daughter at his last moment. However, nothing is said about Kir'ka's daughter whom Kir'ka should logically have as he has a son-in-law. Nor the marital status of Efim's daughter is mentioned in the story. In the field of artistic logic, these images of a man (a son-in-law) and a woman (a daughter) unite to turn into a symbol of the continuation of the lives of the people who have been so fiercely arguing with each other. They are called upon to re-establish the connection of times and the torn parts of the national world. It is interesting that the writer consistently calls the characters of the story Kukushkiny Slezy not by their names but mentioning them as just "a man and a woman" ("muzhchina i zhenshchina"). The world they live in has sort of overcome the acute social confrontations. The conflict of the story, considered autonomously, is generally quite sluggish. But the detail mentioned helps to clarify the writer's intention in his central work of the cycle.

\section{Production costs: Tochka Zreniia as an experimental platform of Shukshin-ideologist and artist}

Shukshin protested when he was called the "chronicler" as he felt the special nature of his realistic creative work, the reasons being not only the desire to evade censorship, but also the peculiar features of creative perception of the world inspired by the fairy-tales, bylinas, short bylinas, verbal stories (he learned to write stories from his mother). The main purpose was not in exclusively truthful, historically precise "reconstruction of life in the forms of life". Good fellows better learn from indirect moralistic 
forms but not from direct ones. Conditionally allegorical works, marking the boundaries in his creative work, became a logical consequence of Shukshin's "fantastic realism" development.

Shukshin's works of his 1966-1968 historical and philosophical cycle served as an "experimental field" for the writer's original ways of "revealing the truth". But they are connected with his other stories in their meaning and form, the stories that are not always marked by such great emphasis on the social and the historical. It is only the fairy-tale novel Tochka Zreniia that truly stands out from the series of "logical" search for new artistic ideas and forms. This fairy-tale novel was written in 1966, but not published up until 1973. It was not understood and accepted by the publishers and theater, went beyond by criticism and literary criticism. Tochka Zreniia really was the starting point for the development of Shukshin's artistic manner which was embodied in Energichnye Liudi (Vigorous people), Do Tret'ikh Petukhov (To the Third Cockcrows) in the most perfect form.

Tochka Zreniia has an abundant number of details introducing the image structure and a system of heroes from Do Tret'ikh Petukhov. In the center of the plot of Tochka Zreniia is the Bride. Do Tret'ikh Petukhov contains a number of brides: Poor Liza, Baba Yaga's Daughter, Milka, Galka, Alka. There are also bridegrooms. Ivan calls himself a "groom for all ages". An important semantic role is played by the songs of the duet of the Optimist and the Pessimist in the first case and the devils in the second fairy-tale novel. The devil appears in Tochka Zreniia: "No tut podskochil Nekto, khromoi i boikii" ("But suddenly Someone jumped. He was lame and lively"). The devils are in the center of the plot action in Do Tret'ikh Petukhov. They don't want to live in the swamp anymore; the Pessimist also compares life to a swamp. One of the engineers of the future and of the "tale we want to create" thinks that there are dark forces, Baba Yaga, and the Dragon. These characters became the ones in Do Tret'ikh Petukhov. There are a number of artistic parallels that could be continued. Still, it is more important to evaluate an independent artistic significance of Tochka Zreniia and the writer's original ideas embodied here, as well as the ideas developed in the "historical and philosophical”, satirical and socio-analytical stories and narratives.

In the official organ of the press Shukshin characterizes his idea of the plot as if a speech from the rostrum: "I set a task to show the harm and danger of two extremes - the indiscriminate blackening of life and hopeless pessimism, on the one hand, and groundless optimism, a kind of smug complacency ("Manilovism"), on the other hand.

The future film was meant to sound a fervent appeal to active participation in the construction of a new life" (Shukshin, 1998, Vol. 3: 510).

No "his" word is said here. The entire passage consists of the conventional ideological propaganda stamps, as if cited from Ostap Bender's "Grand set": ogul'noe ochernitel'stvo ("groundless name-calling"), besprosvetnyi pessimism ("gloomy pessimism"), bespochvennyi optimism ("groundless optimism"), plamennyi prizyv ("fervent appeal”), and stroitel'stvo novoi zhizni ("building of a new life"). From the dictionary of Lenin's favorite critical definitions, Shukshin "borrowed" even the "artistic" comparison of "Manilovism". Such manipulation with the clichés also continues in the text of the fairy-tale novel. The writer's "explanation" of a gist of his work is both a "signal" to regard the action and images primarily from socio-political and ideological "points of view".

The writer chooses an overtly conventional artistic manner of the novel. Each image is a symbolic generalization, and involves interpretation in the process of co-creative 
perception. The reason for the families' meeting is relationship of "children", a bride and a bridegroom, matchmaking. The "fathers" are paid no less attention. Their characters and position sort of explain the current state of affairs and the forces available in modern ideological disputes.

The symbolism of the Bride's image is obvious; it is predetermined by frank literaryideological associations. The Bride's image is mostly essential in N.G. Chernyshevsky's novel Chto delat'? (What Is to Be Done?). Almost directly borrowed image of "future in a light way" as compared to the present is also connected with Chernyshevsky's tradition: "Stena doma Nevesy s treskom raskololas'. I vidno stalo. Vse tak zhe, kak my uzhe videli, I vse tem ne menee ne tak. Liudi te zhe, i vmeste $\mathrm{s}$ tem sovsem drugie. I v komnate vse kak budto tak zhe, da ne tak..." ("The wall of the Bride's house split up with a bang. And it became visible. ....Everything was the way we have already seen, and yet it was different. People are the same, but yet quite different. Everything in the room seemed the same, but not quite...”. The fourth dream of Vera Pavlovna runs: "Nivy - eto nashi khleba, tol'ko ne takie, kak u nas... Polia - eto nashi polia, no takie tsvety teper' tol'ko $\mathrm{v}$ tsvetnikakh u nas... Roshci - eto nashi roshchi... No zdanie - chto eto, kakoi on arkhitektury? Teper' net takoi... Zdes' zhivet mnogo, ochen' mnogo" ("The plowed fields are our grain crops, but not like ours... The fields are our fields, but these flowers are only in our flower beds now... Groves are our groves... But what kind of building is it? What is its architecture? Now, there is no such... Many people live here, too many".

The author of Chto Delat' tried to look into the future, "bright and beautiful". The fairy-tale in Tochka Zreniia, which became a true story, is perceived from different ideological positions. The views on history and modernity were revealed in official and informal discussions of the 1960s. The dispute between the Optimist and the Pessimist covertly transfers the contents of the officially sanctioned mid-60s "debates" on a young hero's paths, participation in building of new lives, and the role of material factors on the modern and planned stages of development. Even the names of the debaters - Alik and Edik - are from the same youth-speculative, "polytechnic" context of the 60-s: "Van'ka, perhaps, is forgotten, and even his name is used only on rare occasions. Eduards, Vladiks, Rustiks are more frequent ones" (Shukshin, 1998, Vol. 3: 406).

"Farsovoe predstavlenie $\mathrm{v}$ chetyrekh stsenakh" ("Farcical performance in four scenes"), a variant of the subtitle of Tochka Zreniia, that is preserved in Shukshin's drafts, obviously assumed the associations of Vera Pavlovna's four dreams. Shukshin's works and later versions of allegorical images, that became the sources of "a heap of nasty quotes" (A. Block) for everyday ideological use, integrate into the associative sphere. They give Shukshin the valuable material for the satirical and allegorical imagery.

It should be noted that the role of Chto Delat' in ideological education was openly and consistently determined not so much by the novel's own merits as by the content and tonality of Lenin's famous words about it: "It is useless to read while you are still wet behind the ears... Has plowed deeply”. In Shukshin's fairytale novel this "logic", which is in stratification of the most important ideas on illustrative and subsidiary ones, is also very essential for understanding the meaning. Chernyshevsky and Chto Delat' are important because they were considered significant by Lenin. The associative links with the problems and imagery of Chto Delat' are especially relevant in connection with the importance of the image of the leader of the revolution in Tochka Zreniia. One should 
necessarily get through a peculiar "double system of protection" from ideological accusations. Shukshin was hardly going to seriously argue with Aliks and Ediks on this or that personality's role of in some way or another clear story. It was not only officially simplified Lenin who became the subject of the parody and not less schematized image, but also the image that was already formed at the turn of the $50 \mathrm{~s}-60 \mathrm{~s}$ in the oppositional dissident spheres (his "second birth" was at the turn of the $80 \mathrm{~s}-90 \mathrm{~s})$.

This should concern the image created by "means of literature and films", implemented into the mass consciousness due to the power of TV. The degree of conformity of a "television picture" with life was thought over by the writer in his 1963 story Kritiki (The Critics). This plot motif is repeated in the fairy-tale novel. The episode with a screen broken because of "distorted life" is almost word for word repeated in the "pessimistic" part of the story. A new technical means of introducing "the most important of the arts" into broad masses of people multiplies and thrives in the "optimistic" part of the story. The newlyweds had to have, according to Chernyshevsky, two rooms and, in the spirit of time, two TVs.

Farcically distorted "cinematographic image" of the revolution leader is consistently linked with the Grandpa in Tochka Zreniia. The discussion about the results of historical and revolutionary development and ways of further movement during the "first" and the beginning of the "second" (late 80s) "thaws" was relevant only for the "top ten thousand" and was often reduced to the opposition of Lenin and Stalin, Leninism and Stalinism. Pessimist Alik critically looks at the current state of the "communal" world ("many, too many people live here"). The Grandpa is a symbol of the revolutionary past that is prompted by the Bride's words: "Rubai, dedushka!" ("Give it straight from the shoulder, grandpa!"). Alik pessimistically evaluates the results of the fathers' revolutionary activities. The Grandpa was pushed into the background of his system of values. He is more or less active only in the first mise en scene. He was later pushed aside as rubbish and reminded him of his place: 'Prosnulsia, - iadovito zametila mat' Nevesty. - Chego ty lezesh ne v svoe delo? Tvoe mesto znaesh gde?.. Skazat"?" ("You have woken up", - the Bride's mother noticed venomously. "Why do you stick your nose in the other people's business? Do you know where you belong?.. Shall I tell you?"). This is a variant of criticism of, so to say, "Stalin's", "totalitarian" model of development.

But in the second "optimistic" part the Grandpa is "very much alive". He is active, energetic, an ideologist and a soul of the family. Public ideas of a "good", "Leninist" version of the "communal" world are primarily connected with this character. It is in the second part in which the Grandpa takes many commonplace features of the propagated "image of Lenin". It is the word "Grandpa" proper brings to mind one of Lenin's party nicknames - Starik (the Old Man). The Grandpa repeatedly emphasizes: "Ia blaagorodnyi chelovek" ("I'm a no-o-oble man"). One can catch a hint at the leader's noble origin here. Whereas the Grandpa was imposed the profession of a carpenter or joiner in the first part of the novel, it turned out that he was a machinist. It should be recollected that Stalin also came from a family of a shoemaker.

An "optimistic" Grandpa is watching at young people "with a sort of old cunning", with a "cunning and kind" smile and is "rubbing his hands" "with the pleasure" to listen to a good dispute. "These are recognizable portrait details that parody the image of Lenin in the literary and cinematographic Leniniana. The Grandpa was born in 1887 that is not difficult to calculate. This year is a turning point in the life of "apocryphal" 
Lenin. Then he expressed, according to the same "apocryphal" sources, a famous idea of the necessity to go "the other way". These words sort of symbolize a human's lawful age, a future leader's birth, his taking on a self-found way.

Another important milestone of the leader's life is his Siberian exile. "Semeinaia zhizn', da eshche $v$ usloviiakh tundry... - Ia kogdato takzhe nachinal") ("The family life even in the tundra conditions... - I started that way"), says the Grandpa in Tochka Zreniia. Lenin's optimism, boundless energy, unbending young will coexist in the Grandpa: "Razve gody mogut starit' cheloveka?.. ("Can the years really age a person..?"). A seemingly absurd question gets its interpretation if bearing in mind the “imperishability' of the leader's body (in the Mausoleum) and his deeds that is sanctified in the classic propaganda poster formula: "Lenin lived, Lenin lives, Lenin will live!”. "In his 79 years" the Grandpa relentlessly condemns the complaints about the years: "Glavnoe, chtoby ne otstaval ot zhizni" ("The main thing is not to lag behind the life"). Lenin's biography can also explain some strange salutation the Grandpa insists on welcoming all the newcomers " $\mathrm{K}$ nashemu shalashu" ("Welcome to our humble abode"). The association is most likely to be with Lenin's famous stay in Razliv. That "Lenin's" hut of branches was repeatedly propagandized by the Soviet literature, painting, cinema.

When creating the image of the Grandpa Shukshin actively uses not only the film associations but also the most important "primary sources" from other spheres. The Grandpa-the writer equates the bayonet and the stylus as the means of struggle with "enemies". During the imperialist war he could bayonet three enemies at once. It can be noted that Tri Istochnika $i$ Tri Sostavnye Chasti Marksizma (Three Sources and Three Component Parts of Marxism), one of Lenin's works, which was made a summary of at all levels, was written before the "imperialist" war, in 1913.

As is well known, the three sources of Marxism are English political economy, French utopian socialism, and German dialectical philosophy. These "three pillars" of Marxism are transformed in their three variants of matchmaking: a roughly materialistic economic version of the Pessimist, an utopian picture of a socialist Paradise of the Optimist, and the "dialectics" of a Magical man that brought the logic to the absurd.

Lenin's work that was next to Three Sources in his complete works published in 1961, which Shukshin could make use of, was Razgovor (Conversation). This little-known work that was not published during Lenin's life was probably another source of the writer's artistic thoughts in Tochka Zreniia. Razgovor is written in the form of a dialogue between two Strangers about the ways and means of the Russian revolutionary movement development. Outsiders are "not involved in direct combat" but they vigorously defend their positions. The first outsider is idealistic and undoubtedly suffers from "fine mindedness" and "Manilovism". He is frightened by the struggle of differently oriented socialist movements that caused people's "disappointment in socialism". Competition in swearing creates an environment of some "unnatural selection", nominating the specialists in boxing for first places (boxing was Shukshin's favorite sport).

The second stranger (whom Lenin's sympathy and position were with) was a militant materialist, optimist. He was not scared with the extremes of struggle: "Ukharstvo.., boks.. neizbezhny vezde, gde est' tolpa, shum, krik, davka" ("Bravado.., boxing... are inevitable wherever there are crowds, noise, screaming, and crush"). The character concludes: "Ia besnuius' tol'ko ot togo, chto ia - postoronnii, chto ia ne mogu rinut'sia v serdtsevinu etoi bor'by" ("I go 
mad just because I'm a stranger and cannot rush into the heart of this struggle") (Lenin, Vol. 23: 51-54).

Some similarities of the composition and the system of images in this Lenin's work and Shukshin's fairy-tale novel are obvious. The figure of a "pessimistic" Groom-boxer alone is enough to prove it. The Grandpa's character and his fighting spirit, that make him very close to the Second stranger, are even more revealing: "Nam nado raskladyvat', nado bichevat', nado peretriakhivat!.. Ia, naprimer, v svoei knige "Ruki vverkh, nepriiateli!" peretriakhivaiu vse na svete" ("We need to reveal, we need to castigate, we need to shake up!.. I, for example, in my Hands up, enemies! I'm shaking all the things up".

In Tochka Zreniia it is not difficult to find the traces of other influences of well-known Lenin's works and statements. The Grandpa's monologue ("Mne nravitsia asha goiachnost, s kakoi vy otstaive vashi bezdeniia. Na moi vzgliad, eokolko zapal'ch,n gm eto ui" / "I like the vehemence which you defend your beliefs with. In my opinion, it is somewhat passionate, but it will go away over the years") contains certain signs of Lenin's speech at the third Congress of the AllUnion Leninist Young Communist League as well as of his "second" criticism of the futurists and Mayakovsky.

The Grandpa's praised Leo Tolstoy almost similarly to the way Lenin from Gorky's essay did it: "Kakaia glyba, a? Kakoi materyi chelovechishche! Vote to, baten'ka, khudozhnik... I-znaete, chto eshche udivitel'no? Do etogo grafa podlinnogo muzhika $\mathrm{v}$ literature ne bylo" ("What a block he is, huh? What an experienced man! He is a real artist... And do you have an idea of what else is amazing? There was no true muzhik in literature before this count"). Shukshin's author of Ruki vverkh, nepriiateli exclaims: "Kakaia povest'!.. Umel zakruchivat' graf Tolstoi. A? Master, master... No trudnoe eto delo! Okh, trudnoe!" ("What a story it is!.. How skillfully could count Tolstoy make his plot twists? Huh? Master, master... But it's a hard case! A very hard case!"). The theme, a typical expressive-and-emotional "Leninist" style, and tonality of evaluations are similar. Shukshin also preserves the subsequent arguments of Gorky's Lenin about the relations of rough and cruel reality and relaxing softness of art: "Chasto slushat' muzyku ne mogu, deistvuet na nervy, khochetsia milye gluposti govorit' i gladit' po golovkam dliudei... A segodnia gladit' po golovke nikogo nel'zia - ruku otkusiat, i nado bit' po golovkam, bit' bezzhalostno" ("I cannot often listen to music that is getting on my nerves; I'd like to say cute stupidity and pat the people on the heads... But I can pat on nobody's head today as they will grab my arm, and one must blow the heads, blow mercilessly"). However, Shukshin sort of turned it inside out: "Inoi raz takoe volnenie okhvatit, dumaesh: luchshe by ia emu v mordu dal, otritsatel'nomu geroiu kakomunibud', khochetsia, izviniaius', matom kryt', a prikhoditsia pisat', chto nazyvaetsia, kor-rektno" ("Now and then you are overwhelmed with the excitement and think: I'd rather strike him in the face, the face of some villain. I'm sorry but I'm eager to cuss out. Yet, I have to write what they call it correctly".

The positions of Gorky - "the critical realist", unmasking the leaden abominations of the reality, serve the basis for the philosophy of the Pessimist's life. Direct reference to Gorky's theses about the Russian national character and life - "Khotel by ia znat', kak vy eto boloto prevratite v skazku. Bul'dozerami, chto ly? Zasyplete?" ("I'd like to know how you will turn this swamp into a fairy-tale. Will you fill it in by bulldozers or what?") - becomes apparent near almost a verbatim "quote" from Gorky: "My favorite thing to do is to look into the strangers' windows. And what do I see there? 
Only leaden abominations". Gorky's "leaden abominations" expression is actively used in his autobiographical trilogy. One of its stories, Liudi (The People), run: "Na dal'nikh ulitsakh mozhno bylo smotret' $\mathrm{v}$ okna nizhnikh etazhei, esli oni ne ochen' zamerzli ili ne zanavesheny iznutri. Mnogo raznykh kartin pokazali mne eti okna: videl ia, kak liudi moliatsia, tseluiutsia, igraiut v karty, ozabochenno i bezzvuchno beseduiut, peredo mnoiu, tochno v panorama za kopeiku, tianulas' nemaia, ryb'ia zhizn"” ("There, in the far-away streets, one could peep into the windows of the lower floors if they were not too frozen or curtained from inside. These windows showed me many different pictures: I saw people praying, kissing, playing cards, silently talking with concern. A mute fish life was stretching in front of me, as if in a panorama, for a kopeck").

A pessimistic view on the state of modern life is as far from the truth as an optimistic one. Empty public debates could not be filled with meaning even with the help of omnipotent philosophical dialectical triads: "The point is to combine both points of view and think of the third one resulting from a tense philosophical act!" The "dialectic" scene, variant is "the Bride's family as they are seen by our Optimist. The Groom's family as they are seen by the Pessimist" is a complete self-destruction of speculative evaluations of the past and projects of the future. The owner of time and history, a Magical person loses the ability to control them on his own volition: "Chasy svistnuli" ("The watch gave a hissing sound"). The history took a non-programmed way that no scenarios specified. "High Revival" did not take place. "We came earlier", says the Groom, a boxer and a cad. At that he "won't hear" the Bride, talking about a specific naked person. He "hears" the author. The mysterious dialogue between the Bride and the Groom expresses the writer's observations over the discoveries and losses on his path.
It is the Unclear someone who turns out to be a true master of the situation on the modern stage. "In the context of research it is the first stage" of the communist social formation. It is socialism that admits material interest, commodity-money relations, etc. It is this basis that Lizunov builds his own dominance in the society on. In the first part his dominance was purely economic; in the second part it was based on the possession of "knowledge", information that was coded and thus beyond the comprehension of those who are not well-informed, small fries: "Izuchaiu iazyk drevnikh artabov. Zashchishchaiu diplom i edu na Krainii Sever" ("I learn the language of the ancient Arabs, then defend my diploma and go to the Far North"), what makes the Grandpa evaluate Tolik's knowledge as a sign of the new elite, "no-o-obility".

Whereas the both fathers' memories about their stay in the Far North sound like an echo of the recent GULAG's past, the Unknown's reference to it is thought to have quite different accents. They can be understood by referring, for example, to the story Srezal (Having Cut). Pseudo-scientific "nonsense" is intended to protect social benefits or to get them. Having made the right move, the graduate philologist hopes for it: "Ia ubezhden, chto moe znanie drevnearabskogo iazyka prigoditsia $\mathrm{v}$ surovoi tundra... A poka ia zhivu v obshchezhitii, gol kak sokol, za dushoi - ni kopeiki. Vse - v budushchem" ("I am convinced that my knowledge of the Old Arabic will prove useful in the harsh tundra... But for the present, I live in a hostel and I am as poor as a church mouse, without a kopeck to my name. Everything is ahead in the future"). The Groom's behavior is blamed for his mercantilism. Yet, he does not change it. Tolik, in his turn, is more knowing and of a more exquisite nature, but his aspirations are the same.

Evgenii Elizarovich Lizunov is the only hero in the fairy-tale novel who cannot be easily 
understood. At first glance, the name seems somewhat surprising and unmotivated. The surname of Lizunov was once used by Shukshin in the story Sel'skie Zhiteli (The Villagers). Lizunov was the name of the head of the school economy, who frightened old Wife Malan'ya by his "air-horrors" ("the human remains are only three hundred grams"). There is some psychological connection between this character and the character from Tochka Zreniia, who won the victory and outgalloped the others. The position of this hero as well as the role of the Leninist context in this work suggests specific sources of his possible "roots". It is likely that this character personified the features of two real historical figures that were important for the writer.

M.T.Elizarov, Lenin's brother-in-law, the husband of his older sister Anna, was a very businesslike, enterprising person who built his relations with the authorities primarily on a legal basis. He publishes many Bolsheviks' works, including those by Lenin himself. Lenin particularly admired his ability to play chess. In his letters Lenin reports with envy and delight that Elizarov managed to beat (in simultaneous game sessions) Lasker and Chigorin, the best chess players of that time.

Lenin used to recall the works by Eugene Lysis, a French economist. They served the basis to argue that France, the homeland of European revolutionism, has long lost its revolutionary signs and that "France is, in fact, a financial oligarchy" (Lenin, Vol. 44: 281), and in general "the unprecedented dominance of only a few banks, financial kings, and financial magnates, who actually turn the most free republics into financial oligarchies, has developed" in Europe and America, presuming their progressiveness (Lenin, Vol. 44: 216).

An enterprising tenant with a "composite" name of Evgenii Elizarovich Lizunov makes calculated, agile moves, thus, taking the first role, becoming the queen but not a pawn, and then busily and wearily takes on the responsibility to be in charge of the school economy, starts organizing his own affairs and providing for his comfort and convenience: "Prostite, vannochku mozhno priniat'? I mne by makhrovoe polotentse i detskuiu shampun'. Perkhot', znaete..." (“I'm sorry but could I take a bath? And I'd like a terry towel and a baby shampoo. Dandruff, you know..."). This hero is obviously a predecessor of the types who are most vividly depicted in Energichnye Liudi (Vigorous People).

In his fairy-tale novel Tochka Zreniia (and in all his works) Shukshin's position is that of the national character. Therefore, no divisions are of paramount importance. That's why the attempts to make Shukshin embrace Stalinism or Leninism, dissidents or theomachists are methodologically inconsistent. Shukshin is on the people's side. The national character constitutes the foundation of his artistic system. It is a reuniting but do not dividing ideological and aesthetic category. Tochka Zreniia is a farcicalsatirical image of neither Lenin nor Stalin, but of what the contradictory and complex phenomena and figures of dramatic national history turned into in the course of the 1960s discussions. Even the tragic Gulag context was made vulgar in the course of these discussions. It became a "fashionable" reason for outlining the "facets", dividing the society, the dividing principle this time being that of "was imprisoned - was not imprisoned". The irony on this matter is felt in a scene of examining the Pessimist by Maluta Skuratov. "The opposition, yes. Only one pose might be left from the whole opposition," speculated the writer (Shukshin, 1998, Vol. 6: 416). Shukshin expressed his own point of view on the national history and the people's tragedy in his peculiar artistic manner in Do Tret'ikh Petukhov. The artistic principle formulated by 
Dostoevsky and manifesting the constructive and unifying function of the national character fully prevailed in his work: "Tragedy and satire are two sisters, walking side by side, their collective name being the truth". This is the only case that proves the morality of those who undertake to speak of the things that are worthy of ridicule or compassion: "Morality is the Truth".

Tochka Zreniia is extremely curious as a material from the creative laboratory of the writer who was looking for his own manner of expression. At the same time, its imageassociative system is apparently overloaded. This results in the writer's cautious attitude to it, the reader's modest destiny and the lack of serious scenography. What makes Shukshin's best works unique is that their most important idea is revealed to everyone who can perceive at least a part of their structural and artistic content, whether the reader is a sophisticated philologist, or a simpleton for whom literary delights and subtleties seem strange. The overall impression is wound up by the course of the plot, the hero's character, association, allusion or metaphor, the element of humor, the dialogues or the writer's judgments... This quality of creativity makes people of different educational and "cultural" levels equally sensitive to the writer's thoughts. Shukshin understood and was able to "consider" in his works all the diversity of forms and ways the people understand the world. Tochka Zreniia displays the completely ready-made and sharpened tools that the writer is going to use. This is what arouses interest to the work under consideration. This also shows the limited nature of its figurative capacity.

\section{Conclusion}

V.M. Shukshin's stories from his 1966-1968 socio-philosophical cycle led to the artistic understanding of the nation's fate, of the dramatic losses the national character suffered on its historical roads of the $20^{\text {th }}$ century, when Herzen's and Chernyshevsky's metaphorical "axe" became a real factor in Russian history, as well as of those surrogates that filled in the spiritual vacuum in the official propaganda as well as in pseudoeducation (obrazovanshchina in Solzhenitsyn's terms) that confronted her but was no closer to the truly national. Shukshin suggests his interpretation of a "new Russian man" (Gorky), a "man with a gun" that became a sign of his time. This external attribute of novelty is there along with the loss of many important traditions of the individual's and the world's spiritual existence.

The writer's views on art, its opportunities and goals caused the signs of the artistic world of the stories and 1967 fairy-tale novel Tochka Zreniia (Point of View). The effect of the circumstances the writer worked in is also felt. Shukshin's ideological image system finds the signs that significantly distinguish it from the literary flow, subject to the laws of the normative aesthetics. The developed principles of poetics characterize a significant part of the writer's prose.

The "specific weight" of the meaning per a "text unit" is extremely high. Shukshin's works are not long, but conceptually richer that the volumes of many works. To understand them one needs rereading them: "True literature is meant for serious reading" (Shukshin, 1998, Vol. 5: 530). In a sense, space is compressed, but communication with a short story requires no less time than reading of a narrative or even a novel. And the space of the "dwarf" can "explode" with new and super-new meanings. As soon as the reader get in touch with it, the story literally draws him into its multidimensional semantic field. Its associations, allusions, covert or overt "citation", appeal to the reader's experience and common sense, urgent reminder about the accepted truth, images, and techniques turn a plane picture into three-dimensional and even multi-dimensional one. The author, narrators and 
characters, depicted in different "mirrors" (even "false" ones) suddenly "scatter" in different directions, and while returning hurry to shout, "throw out" the truth they have discovered. Bright, eye-catching, attention-grabbing initial emotion, thought, and observation are by far not the reader's only important discovery. Another system of reflecting "mirrors" is created by the context of Shukshin's own creativity.

There emerge distant horizons of artistic thought. Age and eternity penetrate in the circle of the writer's thoughts. Tragedies of the last five decades are given the writer's comprehension in their historical dependence, influence on modern national life, and connection with search for the ways of national spiritual healing and rise. The epic task per se results in further structural signs of Shukshin's prose. The writer masters new genres; the artistic world of his stories undergoes significant changes, the role of the principle of cyclization increases.

\section{References}

Anninskii, L. (1977). Put' Vasiliia Shukshina [The Path of Vasily Shukshin], In Tridtsatye semidesiatye [The Thirties - the seventies]. Moscow, $272 \mathrm{p}$.

Apukhtina, V.A. (1986). Proza V.M. Shukshina [V.M. Shukshin's Prose]. Moscow, 96 p.

Chernosvitov, E.V. (1989). Proiti po kraiu: Vasilii Shukshin: Mysli o zhizni, smerti i bessmertii [Passing on the Edge: Vasily Shukshin: Thoughts about Life, Death and Immortality]. Moscow, $240 \mathrm{p}$.

Gorn, V.F. (1990). Vasilii Shukshin. Lichnost'. Knigi [Vasily Shukshin. Personality. Books]. Barnaul, 286 p.

Emel'ianov, L.I. (1983). Vasilii Shukshin: Ocherk tvorchestva [Vasily Shukshin: an Essay on Creative Work]. Leningrad, $152 \mathrm{p}$.

Karpova, V.M. (1986). Talantlivaia zhizn': V. Shukshin-prozaik [A Talented Life: V. Shukshin, a Prose Writer]. Moscow, 302 p.

Kozlova, S.M. (1992). Poetika rasskazov V.M. Shukshina [Poetics of V.M. Shukshin's Short Stories]. Barnaul, 184 p.

Kuliapin, A.I., Levashova, O.G. (1998). V.M. Shukshin i russkaia klassika [V.M. Shukshin and the Russian Classical Literature]. Barnaul, 102 p.

Lenin, V.I.Poln. sobr. soch. 5 izd. Tt. 19, 23, 26, 36, 38, 41, 43, 44 [Complete Set of Works. 5-th Edition. Vol. 19, 23, 26, 36, 38, 41, 43, 44].

O Shukshine: Ekran i zhizn' [About Shukshin: Screen and Life]. (1979). Moscow, 355 p.

Shukshin, V.M. (1998). Sobranie sochinenii: V 6-kn. [Collected Works: in 6 volumes]. Moscow.

Shukshinskaia entsiklopediia [Shukshin Encyclopedia]. (2011). Barnaul, 517 p.

Tolchenova, N.P. (1982). Slovo o Shukshine [A Word about Shukshin]. Moscow, 160 p.

V.M. Shukshin. Zhizn' i tvorchestvo [V.M. Shukshin. Life and Creative Work]. (1997). Barnaul, $170 \mathrm{p}$.

Vertlib, E. (1990). Vasilii Shukshin i russkoe dukhovnoe vozrozhdenie [Vasily Shukshin and Russian Spiritual Revival]. New York, 326 p. 


\section{Как Василий Шукшин отметил \\ пятидесятилетие Октября}

\section{В.К. Сигов}

Московский педагогический государственный

университет

Россия, 119991, Москва, ул. Малая Пироговская, 1/1

Статья посвящена анализу ичикла рассказов В.М. Шукиина 1966-1968 годов, созданных как непосредственный отклик на приближавшееся пятидесятилетие Великого Октября. Рассказы «Миль пардон, мадам!», «Заревой дождь», «Капроновая елочка», «Нечаянный выстрел», «Охота жить», «Операчия Ефима Пьяных» отмечены единой манерой повествования и представляют собой авторский иикл, выразивший представления о сути народного национального характера и его эволюиии под влиянием событий первой половины ХХ века. Рассматривается также повесть-сказка «Точка зрения», любопытная тем, что в ней можно отчетливее увидеть художественный инструментарий писателя, более органично использованный в юбилейном новеллистическом ичикле.

Ключевые слова: «человек с ружьем», интертекстуальность, народный характер, тема коллективизации, ичиклизация рассказов, подтекст, поэтика.

Научная специальность: 10.00.00 - филологические науки. 